Article

\title{
Media Control in the Digital Politics of Indonesia
}

\author{
Masduki \\ Department of Communication, Universitas Islam Indonesia, Indonesia; E-Mail: masduki@uii.ac.id
}

Submitted: 26 February 2021 | Accepted: 11 June 2021 | Published: 21 October 2021

\begin{abstract}
In transitional democratic countries with significant digital media user bases, the "authoritarian turn in digital media" has resulted in new forms of media control designed to counter critical media exposure. This article investigates the ongoing digital pressures experienced by Indonesian media organizations and investigative journalists by the partisan supporters of the country's new authoritarian political leaders. This article provides a critical review of the forms of media control that have emerged in Indonesia within the past five years (2015-2020), giving special attention to the doxing allegedly faced by several news media and journalistic projects: IndonesiaLeaks; Tempo magazine; and WatchDoc. Applying qualitative methods (observation, semi-structured interviews, review of documents), this study finds that the rise of non-state and societal control over critical media leads to self-censorship amongst media and journalists. This study shows that online trolls, doxing, and hyper-partisan news outlets are used as new forms of media control. Control is also exerted by paidsocial media buzzers, whose online identity is established by their use of digital and social media platforms to manipulate information and counter critical news regarding incumbent and oppositional political leaders. This article contributes to the academic debate on the intended forms of media control in digital politics of transitional democracies.
\end{abstract}

\section{Keywords}

digital politics; doxing; Indonesia; journalism; media buzzers; media control

\section{Issue}

This article is part of the issue "Media Control Revisited: Challenges, Bottom-Up Resistance and Agency in the Digital Age" edited by Olga Dovbysh (University of Helsinki, Finland) and Esther Somfalvy (Research Centre for East European Studies at the University of Bremen, Germany).

(C) 2021 by the author; licensee Cogitatio (Lisbon, Portugal). This article is licensed under a Creative Commons Attribution 4.0 International License (CC BY).

\section{Introduction}

In linking the rapid growth of social media platforms with democracy and press freedom, scholars have fallen into two categories. Some academics portray social media as a key driver of an emerging media ecosystem that circles around public participation and democratic accountability (Jenkins et al., 2012; Paterson, 2019). Social media platforms have been hailed as potential saviors of news production, allowing journalists to find new informants and data sources, thereby engaging directly with their preferences and interests (Hermida, 2011; Johansson, 2016). Internet platforms may relieve the press from its reporting obligations, leaving the press free to focus on investigative journalism projects (Anderson et al., 2012).

Other scholars, however, argue that these platforms -rather than allowing users to contribute informa- tion and observations to news production-allow antidemocratic groups to control and manipulate news (Poell $\&$ van Dijck, 2014). Rather than using social media as a tool of deliberative communication (Kangei, et al., 2018), paid-social media users (popularly named buzzers) use free access online platforms to control news and use hate speech to degrade quality journalism.

With those background in mind, this article interrogates the new mechanisms of media control through which social media activity affects the news process and threatens media organizations. This article seeks to scrutinize the practices, motives, and actors of digital threats used to control the media in Indonesian digital politics within the past five years (2015-2020). Special attention will be given to the doxing allegedly faced by several media organizations and journalistic projects: IndonesiaLeaks, a joint collaborative platform 
of several media organizations to investigate corruption among Indonesia's police elite; Tempo, a leading investigative magazine during the revision of the Corruption Eradication Commission Law and the Job Creation Law; and WatchDoc, a documentary production house that explores the links between energy companies and Indonesia's top politicians. This article argues that, rather than enhancing journalistic freedom and media autonomy, the rise of social media has intensified the political pressures experienced by journalists.

Bradshaw and Howard (2019) found organized social media manipulation during Indonesia's 2014 and 2019 Presidential elections, but failed to observe its impact on media independence. Other studies (e.g., Irawanto, 2019; Johansson, 2016; Lim, 2017, 2018; Saraswati, 2018), have used similar approaches to explore the rise of social media buzzers in online political contestations with no observation on their implication to media freedom. Advancing the previous studies, this article will show that both the growing number of buzzers and the practice of media manipulation are new tools for controlling critical media. Doxing and surveillance are particularly used as new forms of media control in Indonesia during 2015-2020. Thus, this study offers an example of a transitional democratic country with a large digital media userbase and its efforts to minimize critical media exposure. This article then aims to re-consider and re-assemble the notion of media control, thereby using Indonesia as a case study to develop a new perspective for understanding media control in the digital age.

This article is ordered as follows. Following this introductory section, it revisits models of media control in the digital age within the context of new authoritarian politics. It also surveys the rise of organized social media manipulation, online trolls, etc. The third section of this article describes the method used in this study, while the fourth and fifth sections offer empirical findings and discussion, with a focus on the doxing allegedly faced by journalists/activists within IndonesiaLeaks, Tempo magazine, and WatchDoc. The sixth section provides this article's conclusions.

\section{Media Control Revisited}

This section elaborates on threats faced by critical media and journalists since the arrival of digital communication technology, viewing them as a form of media control. The term control is generally defined as the power to influence or direct the behavior of a person or agency. Individuals use various ways to exercise this power and negotiate the political interactions within organizations (Bicer, 2020). Control covers various formal and informal arrangements, both centralized and decentralized (Jingrong, 2010). The media, meanwhile, is an institution with the central aim of producing and distributing knowledge in the broadest sense of the word (McQuail, 2010), with journalists as its key actors. In the media sector, control can be exerted through policy, money, and practices, through which political authorities can exercise control over publication licenses, newsrooms, or journalists.

In both democratic and autocratic politics, media control is a key means through which authorities limit the public's access to critical information, thereby securing their political power. In African countries such as Uganda, media and journalists face several threats which include: state intimidation, arrest of those considered critical to the state, and denial of access to public information (Walulya \& Nassanga, 2020). According to Google researchers, 21 of the world's top 25 news organizations have been targeted by hacking attacks, likely by state-sponsored actors (Wagstaff, 2014). Danger is faced not only by those who publish online, but also actors whose journalistic activities interface with digital platform, whether by using computers to process information, using the internet for news gathering and/or research, or simply relying on email for external contact. At an individual media worker, from 1992 to 2021, the Committee to Protect Journalists (CPJ) found 1398 journalists killed including who worked for online media (CPJ, 2021). The CPJ as well as the International Freedom of Expression Exchange have actively documented online attacks against journalists and media organizations, often committed by actors seeking to further sociopolitical goals.

Computational propaganda has increased the media and journalists' risk of digital threats. Threats commonly faced by media outlets include doxing and surveillance, software and hardware exploits, phishing attacks, fake domain attacks, intimidation, harassment, forced exposure of online networks and disinformation, confiscation of journalistic products, and data storage and mining (Henrichsen et al., 2015; Posetti, 2018). Doxing refers to the search for and publication of private or identifying data (about a particular individual) on the internet, typically with malicious intent (Douglas, 2016). Surveillance-the monitoring, interception, and retention of information-is one way that social media buzzers monitor information and the media. Regan (2012) argues that surveillance is often carried out on the grounds of determining power, and often exists without clear policies regarding this information.

Posetti et al. (2020) further found that artificial intelligence technology is being leveraged to create "deepfake" videos and other content designed to discredit targets, including journalists, and especially female reporters. In the case of investigative reporting, when the people being investigated are influential individuals in government, critical media organizations and journalists become the targets or indirect victims (Cottle, 2017). The surveillance technologies are globally diverse, and can include location tracking, facial recognition and monitoring, and bulk interception methods for voice, email, fax, and satellite phone calls to media.

Another common form of media control is the manipulation of information to undermine credible journalism and reliable information. Rumata and Sastrosubroto 
(2018) found that manipulated information is increasingly presented as valid information. Selective information is reproduced and reframed as fact, then redistributed within certain groups via social media. This results in the deliberate targeting of media companies and media professionals, along with their sources, who seek to verify or share critical news and commentaries. More broadly, journalists and media organization have been targeted by acts of "trolling" - deliberate attempts to "misinform or endanger" by sharing information designed to distract their news sources. Journalists might be targeted to trick them into sharing inaccurate data, which feeds a false analysis of the facts or, when it is revealed to be fake, weakens the integrity of their news media.

In the "analog political" era, media control was realized by state officials through direct state censorship, advertising and strict media policies. Meanwhile, in the digital age, media control travels beyond its traditional models. When "traditional" and "new" media technologies have emerged simultaneously in many developing democracies, forms of media control do not replace one another, but combine and compete (Atal, 2017). The actors are no longer state authorities but a network of non-state and paid social media buzzers and/or partisan digital influencers who are seeking both political and economic benefits. They may be considered as a "criminal network." The criminal networks are politically prepared to organize digital violence to control information and investigations that threaten the interests of incumbent political leaders. Unaccountable internet corps and paid influencers play a central role in producing manipulated content to the public. For instance, online abuse and hate speech against journalists, including threats such as phishing, malware, and cyber espionage are on the rise, and have been disseminated via social media and mobile devices (Henrichsen et al., 2015). At the same time, traditional threats continue to occur offline and have found new ways to cause harm and create the hostile environment faced by journalists.

Political motivated buzzers (Felicia \& Loisa, 2019) have become key players in challenging the work of media professionals. Although there is no formal definition, in the context of digital communication, the term buzzer is often used to refer to those with the capacity to influence others via social media, enliven online conversations through their tweets, voice their interests, and get paid for their postings. Buzzers were initially actors seeking to cultivate views or marketers seeking to sell products (Arianto, 2020; Saraswati, 2018; Sugiono, 2020). Yet, they have since become identified with negative promotional strategies used to spread political propaganda.

Buzzers are born and benefit from the social media userbase. They can be seen as autonomous and/or statesupported political actors, incorporated in political campaign strategies to increase the electability and popularity of specific political figures or parties. Bradshaw and Howard (2019) describe that buzzers tend to use automated and human labor to manage fake accounts, through which they convey support for candidates and attack their opponents, thereby polarizing (dividing) society. Such accounts may also be used to disseminate disinformation. Jati (2017) describes buzzers as working to produce kul-twit (twitter lectures) or mini-stories using academic and technocratic language, distributing messages using anonymous accounts, and "testing the water" of politics. Their discourse is only temporary, being used to gauge the actions and responses of middleclass social media users.

It can be concluded that digital politics present new forms of media control. Seeking to ban or at least delegitimize journalistic works (critical news to political authorities), social media buzzers employ threats to media and their journalists. In this sense, control over media acts to undermine their role in advancing the interests of the public. Threats commonly faced by media outlets include doxing and surveillance, software and hardware exploits, fake domain, partisan websites, and personal intimidation. Online threats may be made individually, or combined with offline ones in the interest of chilling critical views and quashing media freedom (Ruffini, 2018). At the same time, physical abuse-potentially fueled by online incitement and designed to suppress analytical reporting-continues (Posetti, 2018).

Such attacks are motivated and influenced by a variety of factors and interests, including the politics, social, and economic contexts where information controls are applied. They are also influenced by the available communications infrastructure, such as the number of internet service providers, and the overall level of internet penetration and growth. As for motive, such attacks desire to distract journalists and media outlets from their investigations by prompting fruitless lines of inquiry that stymie reporting efforts and, ultimately, have a chilling effect on truth-seeking. Examples of this style of misdirection include the struggled reframing of claims about the size of the crowd at Donald Trump's inauguration in 2017 as alternative facts (Smith, 2017). The fabrication of the event designed to trick journalists and US citizens, along with structured social media campaigns aimed at mimicking public response.

\section{Method of Study}

This article is driven by two research questions: What forms of media control have been used within Indonesia's growing digital political propaganda (2015-2020), and how has digital violence been used against media organizations and journalists operating in Indonesia to control their news coverage? Using Indonesia's digital politics as a backdrop, this article explores new patterns of media control based on the findings of a qualitative study conducted between 2019 and 2020 .

Using a qualitative descriptive analysis (Yin, 2014) with a critical perspective, this article examines as much data as possible to describe and explain the diverse 
forms of digitized media control practiced in Indonesia. The qualitative method was used to recognize cases of threats, analyze patterns of media control, and understand the extent to which digital threats are organized by cyber attackers. Analyzed data were collected through observations of selected news websites and social media platforms, semi-structured interviews, and reviews of pertinent documents.

Recognizing the huge number of Indonesian media, as well as their broad experiences with digital threats, this article selected three cases: IndonesiaLeaks; Tempo magazine; and WatchDoc. IndonesiaLeaks is an independent whistleblower platform founded by several media outlets to investigate corruption among Indonesia's police elite. Tempo is a leading news magazine and news website that regularly conducts investigative journalism. Finally, WatchDoc is an independent production house that produces critical documentaries, such as Sexy Killers (2019) - a news documentary exploring the links between energy companies and Indonesia's top politicians that was viewed by 20 million online viewers. These cases were selected to represent three types of journalistic works: a collaborative platform of several news media (IndonesiaLeaks); a recognized news media organization (Tempo, established in 1971); and an individual and independent news production house (WatchDoc).

Following Creswell (2014), this study was conducted in several stages. First, the author collected published documents on acts of digital intimidation committed against media between 2015 and 2020. We assessed official reports from Indonesian media authorities (e.g., Press Council [Dewan Pers], Ministry of Communication and Information Technology), then compared them by reading the annual reports of press, broadcasting, and internet freedom advocacy agencies in Indonesia (e.g., Alliance of Independent Journalists, and SAFEnet). During this stage, we reviewed several aspects of digital violence: number of cases, form, technology used, actor, target, and motive. A longitudinal report by the World of Journalism Study (Muchtar \& Masduki, 2016) provided a broad picture of Indonesian journalistic culture and the challenges faced.

Second, complementing this desk review, between January and July 2020 the researcher conducted semistructured interviews with 10 media professionals who had experienced online intimidation. Particular focus was given to news media executives and individual journalists with Tempo magazine and website, IndonesiaLeaks, and WatchDoc. Informants included; Abdul Manan, a senior journalist to Tempo, chairman of IndonesiaLeaks, and president of the Alliance of Independent Journalists (AJI); Shinta Maharani, the chair of AJl's Yogyakarta branch; Dandhy Dwi Laksono, the owner of WatchDoc; and Heru Margianto, the managing editor of Kompas.com. Interviews were designed with open-ended questions that allowed informants to express their views regarding the rapid rise of social media buzzers/influencers during Indonesian political events (2014-2019), current cases of digital violence against critical media outlets, their individual experiences with threats, and the correlation between said cases and buzzers.

Third, further materials were collected by observing several famous social media platforms, with a particular focus on two types: the social media platforms of individuals who are publicly identified as buzzers, and the social media platforms/websites of anonymous owners and/or operators. Specific attention was paid to their ownership of the platforms, legal position, and conversations on critical news media. In addition, this study observed the official websites of Tempo, Tirto.id, Liputan6.com, and Kumparan, all of which had experienced hacking and information manipulation. Special observation was paid to the news items published.

Finally, conclusions were drawn based on the collected materials and analytical concepts. The typologies of digital intimidation against media actors proposed by media researchers (e.g., Nadzir, 2020; Posetti, et al., 2020) have been used to identify examples of media control, while the views of political scientists (such as Power, 2018) have been used to place the cases in the context of Indonesian politics.

\section{Findings}

This section consists of two features. First, it provides a short description of Indonesia's politics and media system, thereby elucidating the backdrop of this study. Second, to answer its questions on the forms of media control and practice of digital violence against journalists and media organizations in Indonesia, this section explores the use of digital violence as a means of media control in the country's digital politics (2015-2020). The analysis focuses on three cases: Tempo group (both the magazine and the website), IndonesiaLeaks, and WatchDoc.

By May 1998, following the end of Suharto's authoritarian regime, Indonesia had embarked on a mission to adopt a liberal democratic political system. Ultimately, however, the country transitioned from strong direct state control to a more complicated form of political control (Tapsell, 2015; Warburton \& Aspinall, 2019). Today, Indonesian control is marked by oligarchic practices and the rise of digital political contestations between state and non-state actors.

In Indonesia's first ten years of political reorganization (1998-2008), various reforms were implemented in key sectors-including the previously autocratic media system. This strengthened freedom of expression and public participation in the media. Several strategic policies were enacted, including laws on press (1999), broadcasting (2002), and access to information (2008). Combined, these introduced liberal pluralism in media ownership, content production, and deliveries.

At the same time, the Indonesian government welcomed democratic media principles through a series 
of pro-democratic media laws, including Law No. 5 of 1999 on competition, Law No. 40 of 1999 on the press, and Law No. 32 of 2002 on broadcasting (Ministry of Communication and Information Technology of Indonesia [MCIT], 2020a, 2020b). At the time of legislation (1998-2002), political authorities shared the vision that several media policies were necessary to guarantee media independence. However, when the new authorities consolidated during the second decade of political reform, promoting media freedom remained a "big job," as it was challenged by the state-controlled culture that persevered in the new political climate, the monopolistic media ownership, and the rapid rise of paid political cyber-troops.

On the regulatory side, there were contradictions in media policy. For instance, the Press Law offers protections to journalists, but the Information and Electronic Transactions Law (Law No. 19 of 2016, also known as the ITE Law, MCIT, 2020c) contains articles that threaten journalists with imprisonment, and indeed the law has been used for direct attacks against media professionals. The ITE law limits online journalistic practices by threatening journalists with up to six years' imprisonment or fines of up to one billion IDR $(\$ 106,000)$ for online defamation. For instance, SAFEnet, a digital rights defender throughout Southeast Asia, notes that at least 14 charges were levied against media organizations and journalists between 2008 and 2020 (SAFEnet, 2021). Further, SAFEnet (2021) finds the revision of the ITE law, discussed in the Indonesian policymakers between 2020-2021, could also provide the ruling government with a major tool to control news media and promote violence against human rights activists.

Indonesia is home to more than 175 million social media users that spend an average of 4.5 hours per day connected to internet. These fantastic numbers have proven attractive to politicians, which is reflected in the emergence of buzzers. Although buzzers are commonly defined as celebrities with at least 2,000 followers, the case in Indonesia is quite different: According to one Reuters' article, Indonesia's buzzers are not only celebrities, but also "ordinary people" or community members (Tapsell, 2019). As noted by Tapsell (2019), both Prabowo and Joko Widodo (Jokowi) clearly had "social media buzzer" teams running to shape digital discourse while concurrently countering and producing hoaxes and "black campaign" material. The Indonesia Corruption Watch has discovered that, since 2017, the Jokowi's administration has spent Rp 90,45 billion to fund influencers. For instance, as of late 2020, the government has yet to admit that it paid influencers to endorse the job creation bill (UU Cipta Kerja). This bill was criticized for prioritizing business interests at the expense of facilitating exploitative labor and ecological degradation.

Freedom House (2020a) reported that both Jokowi and Prabowo hired online campaign strategists to mobilize paid commenters and automated accounts to spread political advertising ahead of the 2019 election. The agency claims that one buzzer operated approximately 250 fake social media accounts on platforms such as Facebook, YouTube, and Twitter, and these and similar spam accounts amplified hashtags to benefit specific presidential candidates and control public interest media and journalism.

Freedom House (2020b) reports that, overall, press freedom in Indonesia has gradually declined, with the country's rank decreasing from 57 in 2002 to 124 in 2018 (from "free" to "partly free"); the country was again ranked "partly free" in the 2019 survey, which may be attributed to the rise of partisan websites, disinformation, and doxing against media professionals. Similarly, Reporters Without Borders (2018) ranked Indonesia 119th out of 179 countries, a significant drop from its 2002 peak (57th of 139 countries). As such, even as internet penetration has increased steadily, Indonesian media actors and journalists face new forms of control.

The following discussion exposes three popular cases of media control that have contributed to Indonesia's decreased press freedom, thereby showcasing how digital communication is used in efforts to control media and critical information. Investigative journalistic works are the main targets of harassment. Tempo magazineIndonesia's leading investigative news agency-is the most targeted media for cyber intimidation, followed by IndonesiaLeaks and WatchDoc. Recognizing this condition, this article's discussion will begin with a discussion of the Tempo magazine case.

Three types of digital attacks - hacking, doxing, and surveillance-have been organized by digital attackers to control Tempo magazine. Each received public attention and invited public protests. Tempo, established in 1971, had previously been forced to shut down in 1994 amid claims by the Suharto power that the media threatened national stability. Publication of the magazine could not be resumed until 1999. Between 2015 and 2020, the magazine faced much online abuses over its investigative journalism on acting political powers. For instance, in mid-2020, the magazine's homepagehttps://majalah.tempo.co-was hacked and changed with accusations that it was promulgating fake news (referring to its previous investigation of the network of buzzers supporting President Jokowi's Job Creation Law). Action was also taken by buzzers in response to Tempo's political news allegation that the president was attempting to establish a political dynasty after his son Gibran Rakabuming Raka and son-in-law Bobby Nasution contested (and won) mayoral races in Solo and Medan (Tempo, 2020). On an almost weekly basis, Tempo has been threatened for its criticism of the Jokowi's political administration. The cover of the magazine's September 14, 2019, issue attracted public outrage for depicting Jokowi alongside the silhouette of Pinocchio as part of its weekly investigative report entitled "Janji Tinggal Janji" ("promises remain promises"; Tempo, 2020). 
Since 2014 to 2020, the magazine's webpage Tempo.co has faced doxing and surveillance. Several attacks have been found using various hashtags, such as \#TempoAsu. One group-calling itself Zone Injectorgained control of the homepage and replaced it with the phrase "we warned you, but you did not respond to our good intentions"; the Tempo.co website was down for five minutes (Pebrianto, 2020). Similarly, Tirto.id-a leading data journalism website-found that its site had been infiltrated in 2020. The buzzers replaced several news articles, including those critical of the Jokowi authority's handling of Covid-19 pandemic (Salam, 2020).

At the same time, doxing and surveillance have also been used against the individuals (sources) who provide insight to Tempo and other critical media. Take, for example, the experiences of anti-corruption activists Oce Madril and Rimawan in late 2019, and epidemiologist Pandu Riono. Rahayu et al. (2019) describe this as indicative of a pattern to silence public criticism. Ravio Patra, an independent researcher who had previously been a vocal critic of the Jokowi's young staff, was suddenly imprisoned and reportedly charged with spreading offensive messages on his WhatsApp account. His phone had been hacked, and the messages posted by the hackers (Nadzir, 2020). This action can be seen as a tactic to control public information and reduce quality of journalism provided by Tempo (Couper \& Andriyanto, 2021).

The second popular case of media control is a digital violence to IndonesiaLeaks, a joint collaborative digital platform for investigative journalism. As a tactic to counter the coalition's investigative reporting, its chairman Abdul Manan (the president of the Alliance of Independent Journalist) was reported to the Jakarta Police on October 23, 2018, for a criminal case and to the South Jakarta District Court for a civil lawsuit on October 24, 2018. These reports were filed after the Indonesialeaks published an investigative news piece in December 2017. Called The Red Book Scandal, this report exposed evidence showing that significant amounts of money had been transferred from Indonesia's Corruption Eradication Commission investigators (former senior members of the Police Corps) to elite police officers (Global Investigative Journalism Network, 2018). The story also claimed that bribe money had flowed to General Tito Karnavian, the National Chief of Police.

Following IndonesiaLeaks, five of IndonesiaLeaks' nine media partners-Tempo, Kantor Berita Radio $68 \mathrm{H}$ (KBR), Suara.com, Independen.id, and Jaring.id-faced online bullies after they published the story across several platforms. The report as well as the media was quickly targeted by social media buzzers questioning the report, with hashtags \#IndonesiaLeakshoax and \#petisihoax. KBR's website was hit by a denial-of-service attack, leaving it inaccessible for a few hours.

The digital threats are used to control not only conventional media outlets, but also online-only and small-scale critical media houses, and even freelance journalists-cum-activists. For instance, digital risks to WatchDoc, an independent and Jakarta basedproduction house. One of the most controversial cases was the surveillance, doxing, and organized police reporting of the WatchDoc founder Dandhy Dwi Laksono for his series of critical journalistic works. Laksono is the producer of Sexy Killers (2019), a critical documentary that explores the links between energy companies and Indonesia's top politicians. During its production and public screenings, the WatchDoc platform and its journalists-cum-activists faced several internet trolls of their online posts and physical activities (Prabowo, 2019).

For instance, in the interest to counter his criticism, Laksono was charged with spreading hate speech by the Jakarta police on September 26, 2019, after posting about conflicts in two biggest cites of Papua provinceJayapura and Wamena-on his Twitter account (Dipa, 2019). Laksono was accused of violating Article 28 and 45 of the Electronic Information and Transactions Law and spreading information to fire hatred based on race (Dipa, 2019). On 23 September 2019, he had written about the Papua conflicts including a photo of students who had allegedly been shot during the incident. Laksono's arrest came three weeks after human rights activist Veronica Koman was named a suspect by police after she posted on Twitter account in support of the protesting Papuans, prompting rights groups to condemn the police action (Lamb, 2019).

\section{Discussion}

Media control, it can be seen, is exercised in the digital politics of Indonesia. Between 2015 and 2020, doxing, threats, and surveillance of critical media have all been commonly used for control. In the Suharto's authoritarian era (1960s-1990s), media control had been practiced through direct phone calls to media newsrooms and blackmail, as experienced by Kompas daily in 1965 and 1978, Tempo magazine in 1982 and 1994, and Editor magazine and Detik tabloid in 1994. Significant changes are thus occurring in media control after 1998, not only in the technology, packaging, or tactics used, but also in the actors involved. However, the motivation remains similar: to manage the credibility of the ruling authorities (Ruffini, 2018).

From the above data, we can say that Tempo magazine, IndonesiaLeaks, and WatchDoc offer examples of how media operating in Indonesia have been attacked by digital violence, thereby resulting in control of their news services. Unlike in 1982 and 1994, when the perpetrators of raids were clearly identified, in the digital era hackers' identities are not known. Indeed, in several recent cases, attacks have targeted not only media institutions but also groups of journalists (Parikesit, 2020).

This study finds that control of media in the digital politics is not centralized amongst state administrators. Control is exerted primarily by non-state and 
social media-based buzzers-those whose online identity is established by their manipulation of information on various digital and social media platforms to counter critical news regarding incumbent and oppositional political leaders. They are also considered as paid influencers, which are formally or informally recruited by key political leaders as well as the ruling political administration (Wahidin \& Ridwan, 2020). In the 2014 and 2019 presidential elections, Jokowi and his rival Prabowo Subianto both used social media buzzers or cyber-troops to promote their political campaigns and led many controversial attacks against media and journalists.

At the macro level, the increased control of media and public critics marked the authoritarian turn of Jokowi's politics (Power, 2018). The author sees that Jokowi's political power has taken the authoritarian turn ahead of the 2019 elections through manipulation of powerful law enforcement and security institutions for narrow, partisan purposes, and his political cyber-troop's concerted efforts to block critics of oppositional leaders and human right activists. This leads to the increasingly disempowerment of political opposition through a practice of digital repression that undermines freedom of online political communication and reduces political culpability.

Nadzir (2020) has noticed that, historically, digital platforms have always been integral to President Jokowi's political campaigns, at least since his run in the Jakarta gubernatorial election (2012). He believed that online platforms were crucial political tools. In this sense, his regime's recruitment of social media influencers is not surprising. Nadzir (2020) further finds that, by continuing to fund the campaign after winning the 2019 election, the Jokowi's government risks transferring the digital attacks to media professionals and media organization into day-to-day politics.

Parikesit (2020) notes that these attacks are intended to interfere with the media's work and potentially damage media actors' relationship with their sources or interviewees. It is broadly clear that such action could potentially interfere with freedom of expression, especially within the context of digital rights-i.e., (1) the right to access, (2) the right to expression, and (3) the right to feel safe.

To counter digital attacks, media houses, journalist associations, and the Press Council of Indonesia have organized various actions, including proactively exposing these attacks, filing official reports with police, and exposing attackers, thereby protecting their sources from further online victimization. AJl has regularly monitored the practice of doxing against journalists, and noticed that such actions usually result in persecution. To stop the trend, AJl and other non-profit press freedom agencies joined the Anti-Persecution Coalition in 2017 (Putra et al., 2018). The coalition has formed a crisis center to protect as well as provide legal assistance to victims of persecution and harassment. Meanwhile, responding to a series of digital attacks to control their public service, Tempo has stood by its journalistic principles and avoided criticism based on hatred or political motives. Furthermore, several media agencies have continued to respect the right of reply and covered both sides of stories.

\section{Conclusion}

This article has identified several forms of media control using Indonesia's digital platforms, including doxing, online trolling, surveillance, and information manipulation. It confirms that control of media in the digital era differs significantly from control in the analog era. Actions are organized by non-state actors, individuals, or-commonly-by social media buzzers closely involved with autocratic political leaders. This has signaled an authoritarian turn in Jokowi's politics, yet, it was not severe enough to mark the regime as transitioning democracy.

Through desk reviews and interviews with media executives and journalists, it was found that both media organizations and their informants are threatened by "digital disturbances." It further indicates that, even though journalism has become increasingly digital, Indonesia has become no safer for those expressing critical opinions. Journalists and media actors can reach their audiences more quickly, but threats-both new and old-await them: doxing, police reports, and surveillance. Through digital attacks, media outlets risk retaliation from nonstate groups-particularly buzzers motivated to foster media distrust and escalate political instability.

The findings of this article contribute to the academic debate on the forms of media control exercised in digitalized political culture, mainly in Indonesia. However, this article has only addressed three case studies of media control, excluding other news media and journalistic works within the context of Indonesia's digital journalism. More importantly, this article has concentrated specifically on Indonesia, and thus extended investigation of media control in other transitional democratic countries is needed to compare the forms of media control used in digital politics. Given recent tendencies for media liberalization and the rise of digital/social media use, it remains challenging to study the media freedom and media control practiced by state authorities against non-state and digital-based actors in post-repressive societies.

Overall, this study showed how the digital threats control journalists' activism and critical news media. To agree with Nadzir (2020), whether through doxing, trolling, deactivating personal accounts, or removing articles from news sites, online attacks threaten media autonomy and critical voices in society. When critical voices are bullied into silence, raising public criticism involves considerable risk.

\section{Conflict of Interests}

The author declares no conflict of interests. 


\section{References}

Anderson, C. W., Bell, E., \& Shirky, C. (2012). Postindustrial journalism: Adapting to the presentA report. Columbia Journalism School.

Arianto, B. (2020). Salah kaprah ihwal buzzer: Analisis percakapan warganet di media sosial [An analysis of citizen conversation in social media]. Jurnal IImiah Ilmu Pemerintahan, 5(1), 1-20. https://doi.org/ 10.14710/jiip.v5i1.7287

Atal, M. (2017). Competing forms of media capture in developing democracies. In A. Schiffrin (Eds.), In the service of power: Media capture and the threat to democracy (pp. 19-31). CIMA.

Bicer, C. (2020). The power and politics in organizations. In U. Ucan (Eds.), Discussions between economic agents-socio economic studies (pp. 221-245). Iksad Publications.

Bradshaw, S., \& Howard, P. (2019). The global disinformation order: 2019 global inventory of organized social media manipulation. Oxford Internet Institute.

Committee for Protect Journalist. (2021). 1398 journalists killed between 1992 and 2021. https://cpj.org/ data/killed/?status=Killed\&motiveConfirmed

Cottle, S. (2017). Journalist killings and the responsibility to report. In U. Carlsson \& R. Pöyhtäri (Eds.), The assault on journalism: Building knowledge to protect freedom of expression (pp. 21-33). Nordicom.

Couper, E., \& Andriyanto, H. (2021, January 17). How Tempo outrages Jokowi supporters. Jakarta Globe. https://jakartaglobe.id/news/how-tempo-outragesjokowi-supporters

Creswell, J. (2014). Research design: Qualitative, quantitative and mixed methods approaches (4th ed.). SAGE.

Dipa, A. (2019, September 27). Filmmaker Dandhy Laksono named 'hate speech' suspect for tweeting about clashes in Papua. Jakarta Post. https:// www.thejakartapost.com/news/2019/09/27/ filmmaker-dandhy-laksono-named-hate-speechsuspect-for-tweeting-about-clashes-in-papua.html

Douglas, D. (2016). Doxing: A conceptual analysis. Ethics and Information Technology, 2016(18), 199-210. https://doi.org/10.1007/s10676-016-9406-0

Felicia \& Loisa, R. (2019). Actor network and cohort cultures in the business of political buzzer. In A. P. Irawan (Ed.), Proceedings of the Tarumanagara International Conference on the applications of social sciences and humanities (TICASH 2019) (pp. 309-315). Atlantis Press.

Freedom House. (2020a). Freedom on the net 2020: Indonesia. https://freedomhouse.org/country/ indonesia/freedom-net/2020

Freedom House. (2020b). Freedom in the world 2020: Indonesia. https://freedomhouse.org/country/ indonesia/freedom-world/2020

Global Investigative Journalism Network. (2018). Indonesialeaks: Officials attack first investigative report from whistleblower platform. https://gijn.org/2018/ 10/25/indonesialeaks-officials-attack-firstinvestigative-report-from-whistleblower-platform

Henrichsen, J., Betz, M., \& Lisosky, J. (2015). Building digital safety for journalism: A survey of selected issues. UNESCO.

Hermida, A. (2011). Mechanisms of participation: How audience options shape the conversation. In J. Singer, D. Domingo, A. Heinonen, A. Hermida, S. Paulussen, T. Quandt, Z. Reich, \& M. Vujnovic (Eds.). Participatory journalism: Guarding open gates at online newspapers (pp. 13-33). Wiley.

Irawanto, B. (2019). Making it personal: The campaign battle on social media in Indonesia's 2019 Presidential election. ISEAS Yusof Ishak Institute, 2019(28), 1-11. https://www.iseas.edu.sg/images/pdf/ISEAS_ Perspective_2019_28.pdf?

Jati, W. (2017). Aktivisme kelas menengah berbasis media sosial: Munculnya relawan dalam Pemilu 2014 [Middle class activism in social media: The emergence of volunteerism in the 2014-presidential election]. Jurnal IImu Sosial Dan IImu Politik, 20(2), 147-162. https://doi.org/10.22146/jsp.24795

Jenkins, H., Ford, S., \& Green, J. (2012). Spreadable media: Creating value and meaning in a networked culture. NYU Press.

Jingrong, T. (2010). The crisis of the centralized media control theory: How local power controls media in China. Media, Culture and Society, 32(6), 925-942. https://doi.org/10.1177/0163443710379665

Johansson, A. (2016). Social media and politics in Indonesia. Stockholm School of Economics Asia.

Kangei, L., Nyabul, P., \& Muhenda, J. (2018). Habermasian deliberative democracy nuance: An enquiry. International Journal of Advanced Scientific Research, 3(5), 45-53.

Lamb, K. (2019, September 5). Outcry as Indonesia seeks to arrest renowned West Papua rights lawyer. The Guardian. https://www.theguardian.com/world/ 2019/sep/05/outcry-as-indonesia-seeks-to-arrestrenowned-west-papua-rights-lawyer

Lim, M. (2017). Freedom to hate: Social media, algorithmic enclaves, and the rise of tribal nationalism in Indonesia. Critical Asian Studies, 49(3), 411-427. https://doi.org/10.1080/14672715.2017.1341188

Lim, M. (2018). Disciplining dissent: Freedom, control, and digital activism in Southeast Asia. In R. Padawangi (Eds.), Routledge handbook of urbanization in Southeast Asia (pp. 478-494). Routledge

McQuail, D. (2010). Mass communication theory. SAGE.

Ministry of Communication and Information Technology of Indonesia. (2020a). Undang-undang Republik Indonesia nomor 40 tahun 1999 tentang pers [Law No. 40 of 1999 on the Press].

Ministry of Communication and Information Technology of Indonesia. (2020b). Undang-undang Republik Indonesia nomor 32 tahun 2002 tentang penyiaran [Broadcast Law No. 32/2002]. 
Ministry of Communication and Information Technology of Indonesia. (2020c). Undang-undang Republik Indonesia nomor 19 tahun 2016 tentang informasi dan transaksi elektronik [Information and Electronic Transaction Law No. 19/2016].

Muchtar, N., \& Masduki. (2016). The worlds of journalism study: Indonesia. Worlds of Journalism Study.

Nadzir, I. (2020). Hackers, doxers and influencers: The limits of political participation on social media. Indonesia at Melbourne. https://indonesiaatmelbourne. unimelb.edu.au/hackers-doxers-and-influencersthe-limits-of-political-participation-on-social-media

Parikesit, B. (2020). The impact of surveillance on journalist activism. Forum IImu Sosial, 47(2), 55-63. https:// doi.org/10.15294/fis.v47i2.27057

Paterson, T. (2019). Indonesian cyberspace expansion: A double-edged sword. Journal of Cyber Policy, 4(2), 216-234. https://doi.org/10.1080/23738871. 2019.1627476

Pebrianto, F. (2020, August 21). Begini kronologi peretasan situs Tempo.co [The chronology of hacking to Tempo.co]. Tempo. https://nasional.tempo.co/ read/1377884/begini-kronologi-peretasan-situstempo-co

Poell, T., \& van Dijck, J. (2014). Social media and journalistic independence. In J. Bennett \& N. Strange (Eds.), Media independence: Working with freedom or working for free? (pp. 182-201). Routledge.

Posetti, J. (2018). Combatting online abuse: When journalists and their sources are targeted. In J. Posetti \& C. Ireton (Eds.), Journalism, fake news and disinformation (pp. 109-119). UNESCO.

Posetti, J., Aboulez, N., Bontcheva, K., Harrison, J., \& Waisbord, S. (2020). Online violence against women journalists. UNESCO.

Power, T. (2018). Jokowi's authoritarian turn and Indonesia's democratic decline. Bulletin of Indonesian Economic Studies, 54(3), 307-338. https://doi.org/ 10.1080/00074918.2018.1549918

Prabowo, H. (2019, April 15). Duduk perkara penghentian paksa nobar Sexy Killers di Indramayu [The chronology of forced stop to watch Sexy Killers movie in Indramayu]. Tirto.id. https://tirto.id/dudukperkara-penghentian-paksa-nobar-sexy-killers-diindramayu-dmaR

Putra, J., Manan, A., Madrin, S., \& Murti, H. (2018). Doxing, persecution, and violence threatening journalists in Indonesia. In M. Hellema, C. Yi-Lan, \& O. Motiwala (Eds.), Freedom of expression under threat: Perspective from media and human right defenders in Asia (pp. 17-22). FORUM ASIA.

Rahayu, K., Yogatama, B., \& Patricia, S. (2019, September 24). Yang vokal yang diretas (1) [The hacked vocals]. Kompas. https://kompas.id/baca/utama/2019/09/ 24/yang-vokal-yang-diretas-1

Regan, P. (2012). Regulating surveillance technologies. Routledge.

Reporters Without Borders. (2018). Online harassment of journalists. https://rsf.org/en/news/rsf-publishesreport-online-harassment-journalists

Ruffini, P. (Ed.). (2018). Underneath the autocrats: Southeast Asia media freedom report 2018-A report into impunity, journalist safety and working conditions. International Federation of Journalists.

Rumata, V., \& Sastrosubroto, A. S. (2018). Net-attack 2.0: Digital post-truth and its regulatory challenges in Indonesia. In R. Panuju (Ed.), Proceedings of the International Conference of Communication Science Research (ICCSR 2018) (pp. 116-120). Atlantis Press.

SAFEnet. (2021). Peluncuran laporan situasi hak-hak digital di Indonesia tahun 2020: Represi digital di tengah pandemi [Reports on human right situation in Indonesia 2020: Digital repression during pandemic]. https://id.safenet.or.id/2021/04/peluncuranlaporan-situasi-hak-hak-digital-di-indonesia-tahun2020-represi-digital-di-tengah-pandemi/

Salam, F. (2020, August 24). Kronologi peretasan berita Tirto.id, dua artikel soal 'Obat Corona' [The chronology of hacking to Tirto.id news: Two articles about Corona medicine]. Tirto.id. https://tirto.id/kronologiperetasan-berita-tirtoid-dua-artikel-soal-obatcorona-fZ2d

Saraswati, M. (2018). Social media and the political campaign industry in Indonesia. Jurnal Komunikasi Ikatan Sarjana Komunikasi Indonesia, 3(1), 51-65.

Smith, D. (2017, January 23). Sean Spicer defends inauguration claim: 'Sometimes we can disagree with facts.' The Guardian. https://www.theguardian.com/usnews/2017/jan/23/sean-spicer-white-house-pressbriefing-inauguration-alternative-facts

Sugiono, S. (2020). Fenomena industri buzzer di Indonesia: Sebuah kajian ekonomi politik media [The industry of buzzers in Indonesia: A political-economic analysis]. Communicatus: Jurnal IImu Komunikasi, 4(1), 47-66. https://doi.org/10.15575/cjik.v4i1.7250

Tapsell, R. (2015). Indonesia's media oligarch and the 'Jokowi phenomenon.' Indonesia, 99, 29-50. https:// www.jstor.org/stable/10.5728/indonesia.99.0029

Tapsell, R. (2019, March 22). The polarization paradox in Indonesia's 2019 elections. New Mandala. https://www.newmandala.org/the-polarisationparadox-in-indonesias-2019-elections

Tempo. (2020, December 10). The danger of political dynasties. Tempo. https://en.tempo.co/read/ 1413413/the-danger-of-political-dynasties

Wagstaff, J. (2014, March 28). Journalists, media under attack from hackers: Google researchers. Reuters. https://www.reuters.com/article/us-mediacybercrime-idUSBREA2ROEU20140328

Wahidin, K., \& Ridwan, A. (2020, August 23). Kampanye Buzzer Ciptaker adalah blunder yang ironis [The buzzer campaign is an ironic blunder]. Alinea. https://www.alinea.id/politik/blunder-kampanyebuzzer-omnibus-law-ciptaker-b1ZSc9w80

Walulya, G., \& Nassanga, G. (2020). Democracy at stake: Self-censorship as a self-defence strategy for journal- 
ists. Media and Communication, 8(1), 5-14. https:// doi.org/10.17645/mac.v8i1.2512

Warburton, E., \& Aspinall, E. (2019). Explaining Indonesia's democratic regression: Structure, agency and popular opinion. Contemporary Southeast Asia, 41(2), 255-285. https://doi.org/10.1355/cs41-2k

Yin, R. (2014). Case study research: Design and methods (5th ed.). SAGE.

\section{About the Author}

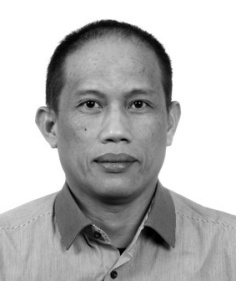

Masduki is an associate professor at the Department of Communication, Universitas Islam Indonesia, Yogyakarta, Indonesia. He earned his PhD at the Institute of Communication Studies and Media Research (IfKW), University of Munich, Germany (2019). He has published several books on the Indonesian broadcasting system and journalism. His articles have appeared in such scholarly journals as GAZETTE, Journalism Studies, Journal of Digital Media and Policy and Media Asia. Masduki has a particular interest in media policy, comparative media systems, broadcasting ethics, media activism, and journalism. 